\title{
Multivariable Robust Regulation of Alkalinities in Continuous Anaerobic Digestion Processes: Experimental Validation
}

\author{
Víctor Alcaraz-González ${ }^{1, * \mathbb{D}}$, Fabián Azael Fregoso-Sánchez ${ }^{1,2}$, Víctor González-Alvarez ${ }^{1}$ \\ and Jean-Philippe Steyer ${ }^{3}$ (D) \\ 1 Universidad de Guadalajara-CUCEI, M. García Barragán 1421, Guadalajara 44430, Mexico; \\ ffregoso@liceodelvalle.edu.mx (F.A.F.-S.); victor.ga@redudg.udg.mx (V.G.-A.) \\ 2 Liceo del Valle, Paseo del Valle 500, Colinas de San Javier, Guadalajara 44660, Mexico \\ 3 INRAE, University of Montpellier, LBE, 102 Avenue des Étangs, 11100 Narbonne, France; \\ jean-philippe.steyer@inrae.fr \\ * Correspondence: victor.alcaraz@cucei.udg.mx
}

\section{check for}

updates

Citation: Alcaraz-González, V.;

Fregoso-Sánchez, F.A.;

González-Alvarez, V.; Steyer, J.-P.

Multivariable Robust Regulation of

Alkalinities in Continuous Anaerobic

Digestion Processes: Experimental

Validation. Processes 2021, 9, 1153.

https://doi.org/10.3390/pr9071153

Academic Editors: Jérôme Harmand, Alain Rapaport, Neli Dimitrova and Ivan Simeonov

Received: 15 May 2021

Accepted: 15 June 2021

Published: 2 July 2021

Publisher's Note: MDPI stays neutral with regard to jurisdictional claims in published maps and institutional affiliations.

Copyright: (c) 2021 by the authors. Licensee MDPI, Basel, Switzerland. This article is an open access article distributed under the terms and conditions of the Creative Commons Attribution (CC BY) license (https:// creativecommons.org/licenses/by/ $4.0 /)$.

\begin{abstract}
A multivariable adaptive feedback control for highly uncertain continuous anaerobic digestion processes is proposed to regulate the volatile fatty acids (VFA) concentration, the strong ions concentrations, and the total and intermediate alkalinities. The multivariable control scheme includes a Luenberger observer to estimate both the unmeasured variables (i.e., VFA) and unknown microbial growth kinetics. The control approach is designed using an exponential Lyapunov function to resemble the typical exponential biological growth of the involved microbial consortia. Taking into account physicochemical equilibrium, alkalinities are represented as a function of the state variables. As a result, the control problem becomes a regulation problem on alkalinities, and in turn, a tracking control problem on the state variables, with two manipulated variables-the dilution rate and the feed rate of a strong alkali solution-while the state variables' set-points are given as a function of $\mathrm{pH}$. The implementation of this multivariable control scheme was experimentally tested and validated in a $0.982 \mathrm{~m}^{3}$ pilot plant treating agro-industrial wastewater and demonstrated to be robust in the face of unknown microbial growth kinetics. Results showed the potential for practical application and optimization of industrial digesters.
\end{abstract}

Keywords: anaerobic digestion; alkalinity; control; multivariable; uncertainties; robustness; wastewater treatment

\section{Introduction}

Anaerobic digestion (AD) is a very complex biological process used for treating agroindustrial wastewaters with a high variety of organic long-chain compounds, such as carbohydrates, lipids, and proteins. Expressed as the chemical oxygen demand (COD), these compounds represent the substrate for a consortium composed of a large variety of microorganisms that decomposes the organic matter in the absence of oxygen into microbial biomass, residual organic matter, and biogas (mainly composed of methane and carbon dioxide). $\mathrm{AD}$ is one of the most widely used bioprocesses for treating agro-industrial effluents [1-4], capable of directly treating high organic load wastewater $\left(10-80\right.$ gCOD L $\left.^{-1}\right)$ [5-8]. It is relatively easy to implement in practice [9], reaches high removal yields (between 90 and $98 \%$ COD) $[4,10]$, and produces an added-value byproduct-biogas-which is rich in methane $(60-70 \%$ content) [10] and may be used as fuel or recycled in the grid $[7,11]$. In contrast, $\mathrm{AD}$ processes may present some operating difficulties since the excessive accumulation of volatile fatty acids (VFA) may lead the process to a breakdown. Moreover, it is well known that AD exhibits a highly nonlinear behavior [12,13], which makes any control scheme more difficult to design and develop. Furthermore, it has one of the most diverse ecosystems in nature [14,15], and their growth kinetics are difficult to model $[16,17]$. In addition, even when $\mathrm{AD}$ withstands high organic loads, drastic process input step changes 
may result in a partial or even complete loss of operational stability (OS) [18,19]. Particularly, regarding this last issue, alkalinity is recognized among the most important variables for preserving the OS in AD processes [20,21]. On the other hand, it has been reported that a relatively high presence of strong ions provokes unbalancing of the physicochemical equilibrium and may result in inhibition that directly affects the methanogenic archaea population [22,23] and eventually the bioprocess acidification [24-27]. When this takes place, the system is wrapped in a vicious circle: higher acidification, greater inhibition, and greater inhibition, greater acidification; thus, the system collapses. Thereby, the main inhibition indicator, and thus also of OS, is alkalinity, because it involves all the physicochemical system equilibria [28-30].

Only a few studies have been developed for controlling alkalinity in the past. For instance, Wang et al. [31] developed an artificial neural network to monitor alkalinity whereas Barampouti et al. [32] used a lagged regression model to describe the VFA/bicarbonate ratio's alkalinity behavior in $\mathrm{AD}$ processes. These studies focused on predicting the operating conditions to indirectly prevent the process breakdown. On the other hand, other control approaches also have been conducted to guarantee the operational stability by regulating the $\mathrm{pH}$ or by controlling both the VFA concentration and $\mathrm{pH}[19,33,34]$. However, to the knowledge of the authors, regulating the alkalinity directly has not been fully addressed. The reason for this is simple: only a few dynamical AD models describe alkalinity as a state variable because it is a function of $\mathrm{pH}$. Thus, its derivative with respect to time, though possible, would result in expressions difficult to handle and allocate in control law calculations. In order to facilitate the understanding of the AD process, the International Water Association (IWA) [35] has developed an AD model, the so-called ADM1, which has been extensively used for simulation purposes, state variables monitoring and estimation [36], experimental validation and optimization [37], and even for validating simpler models [38]. The well-known ADM1 model takes into account the cations and anions activities that resulted either in differential equations (DE) or differential algebraic equations (DAE) sets [35,39]; nevertheless, its $\mathrm{pH}$ functionality is not explicit. Recent efforts have been addressed to deal with this important operating variable. For instance, Zhang et al. [40] modified the ADM1 model by integrating a more detailed physicochemical framework and by introducing inorganic carbon and nitrogen balance terms to resolve the discrepancies between the carbon and nitrogen contents, while Shi et al. [41] improved the ADM1 model using a variable stoichiometric approach based on the high hydrogen partial pressures and $\mathrm{pH}$. Although these improvements provide useful information, the high dimension of the modified ADM1 makes it very difficult to implement in process control structures [42]. In this sense, efforts have been made to reduce the ADM1 complexity, which under certain practical and theoretical considerations yields more manageable AD models for control purposes [42-44]. One of these reduced models was developed almost at the same time than the ADM1 model; it is the so-called AM2 model [45], whose structure does not explicitly contain the alkalinity as a function of $\mathrm{pH}$, but does include a state variable named $Z$, which takes into account the concentration of all the strong ions (cations and anions) in the bulk phase, and considers that, at a $\mathrm{pH}$ close to 7 , it is proportional to total alkalinity [43]. By performing the corresponding mass balances, $Z$, the VFA concentration, and the total inorganic carbon concentration become state variables in the AM2 model. It has been successfully experimentally validated on a $0.982 \mathrm{~m}^{3}$ fixed-bed bioreactor pilot plant used for the treatment of red wine vinasses [5]; in fact, the same pilot plant is used in the present work. Indeed, this model has been very useful for describing AD processes, treating mainly soluble, carbohydrate-based organic matter and where degradation of complex and proteinaceous substrates, such as waste-activated sludge, is negligible [43]. In addition, it has been largely used in optimization, parameter and state estimation, and process control approaches in AD (for instance, see [46-49]), as well as in actual instrumentation and control applications [50-53]. This model also has been used for monitoring the ratio VFA/ $Z$ related to the OS in AD, taking into account alkalinity [54] in continuous $\mathrm{AD}$ reactors, and for modeling the alkalinity spatial distribution in an up-flow 
fixed-bed anaerobic digester [55]. The ratio VFA / $Z$ also has been regulated by using a model predictive control (MPC) approach in order to achieve an optimal OS on the basis of a modified AM2 model [56].

The aim in this contribution is to design, develop, and implement a multivariable adaptive feedback controller to regulate the VFA concentration and total and intermediate alkalinities to guarantee the operational stability of the AD process. The controller is a robust multiple-input, multiple-output (MIMO) control, which has been previously described and demonstrated in [57] by using a modified AM2 model and an interval observer for handling process inputs uncertainties. As in [57], alkalinity references are translated into state variable references, taking into account $\mathrm{pH}$ variations. The proposed control scheme is experimentally tested and validated in a pilot plant anaerobic digester, consisting of a $0.982 \mathrm{~m}^{3}$ up-flow fixed-bed bioreactor, located at LBE-INRAE, Narbonne, France. The structure of the control schemes takes into account the high nonlinearity of the $\mathrm{AD}$ process, the unknown microbial growth kinetics, and its parameter uncertainty [57,58]. A Luenberger observer [59] is used in the control scheme to estimate the biomass concentrations (which cannot be measured), together with the kinetics and yield coefficients. It is shown that the proposed robust MIMO control scheme is robust in the face of parameter uncertainty, unknown kinetics, and $\mathrm{pH}$ variations, as well as in measuring disturbances.

\section{Materials and Methods}

\subsection{Anaerobic Digestion Model}

In this work, we used a modified AM2 model, called the AM2a model [57] in which a second input flow, consisting of concentrated $\mathrm{NaOH}$, is added and is the second manipulated variable. This model is given by:

$$
\begin{aligned}
& \dot{X}_{1}=\left(\mu_{1}-\alpha D(t)\right) X_{1} \\
& \dot{X}_{2}=\left(\mu_{2}-\alpha D(t)\right) X_{2} \\
& \dot{S_{1}}=\left(S_{1}^{\text {in }}-S_{1}\right) D(t)-k_{1} \mu_{1} X_{1} \\
& \dot{S_{2}}=\left(S_{2}^{\text {in }}-S_{2}\right) D(t)+k_{2} \mu_{1} X_{1}-k_{3} \mu_{2} X_{2} \\
& \dot{Z}=\left(Z_{1}^{\text {in }}-Z\right) D_{1}(t)+\left(Z_{2}^{\text {in }}-Z\right) D_{2}(t)
\end{aligned}
$$

with $\mu_{1}=\frac{\mu_{\max 1} S_{1}}{k_{S_{1}}+S_{1}}$

$$
\mu_{2}=\frac{\mu_{\max 2} S_{2}}{k_{S 2}+S_{2}+\left(S_{2} / k_{I}\right)^{2}}, \text { and } D(t)=D_{1}(t)+D_{2}(t) \approx D_{1}(t)
$$

where $X_{1}$ and $X_{2}$ represent the acidogenic and methanogenic biomass concentrations, respectively, $S_{1}\left(\mathrm{~g} \mathrm{~L}^{-1}\right)$ is the organic matter concentration expressed as chemical oxygen demand (COD), and $S_{2}\left(\mathrm{mmol} \mathrm{L}^{-1}\right)$ is the VFA concentration. $D_{1}(t)\left(\mathrm{d}^{-1}\right)$ is the main dilution rate and $D_{2}(t)\left(\mathrm{d}^{-1}\right)$ corresponds to the concentrated alkali solution dilution rate (here, it is assumed that $D_{2}(t)<<<D_{1}(t) . Z\left(\mathrm{mEq} \mathrm{L}^{-1}\right)$ is the strong ions concentration, where $Z_{1}^{\text {in }}\left(\mathrm{mEq} \mathrm{L}^{-1}\right)$ and $Z_{2}^{\text {in }}\left(\mathrm{mEq} \mathrm{L}^{-1}\right)$ are the strong ion concentrations in the main and second input flows, respectively. $\mu_{1}\left(\mathrm{~d}^{-1}\right)$ (Monod type) and $\mu_{2}\left(\mathrm{~d}^{-1}\right)$ (Haldane type) are the microbial specific growth rates for acidogenic bacteria and methanogenic archaea, respectively, where $\mu_{\max 1}$ and $\mu_{\max 2}\left(\mathrm{~d}^{-1}\right)$ are the maximum growth rates $k_{S 1}\left(\mathrm{~g} \mathrm{~L}^{-1}\right)$, and $k_{S 2}\left(\mathrm{mmol} \mathrm{L}^{-1}\right)$ represent the half saturation constants while $k_{I}\left(\left(\mathrm{mmol} \mathrm{L}^{-1}\right)\right)^{1 / 2}$ represents the inhibition constant. Parameters $k_{1}$ to $k_{3}$ are yield coefficients in the corresponding units. Parameter $\alpha$ (dimensionless) denotes the biomass fraction that is retained for the bioreactor bed; i.e., $\alpha=0$ stands for an ideal fixed-bed reactor, while $\alpha=1$ stands for an ideal continuous stirred reactor tank [45]. 


\subsection{Control Objectives}

According to $[20,33,57,60,61]$, operational stability can be held by keeping the following alkalinity criteria:

$$
\begin{gathered}
T A \geq 3 \mathrm{gCaCO}_{3} \mathrm{~L}^{-1}\left(\text { i.e., } 60 \mathrm{mEq} \mathrm{L}^{-1}\right) \\
I A / \mathrm{TA} \leq 0.3
\end{gathered}
$$

where $I A$ represents the intermediate alkalinity, and $T A$ represents the total alkalinity. Both $I A$ and $T A$ can be measured by simple titration using the method proposed by Ripley et al. [20], which consists of bringing the $\mathrm{pH}$ in a solution from the initial $\mathrm{pH}_{0}$ to $\mathrm{pH}_{1}=5.75$ (first point of titration) and then to $\mathrm{pH}_{2}=4.3$ (second point of titration). However, as it was stated above, and as it can be seen in Model (1), neither TA nor IA are state variables. Then, the reference inequalities (3-4) have been translated into true state variables, according to $[57,60]$, as follows:

$$
\begin{gathered}
T A \equiv f_{T c} Z(t)+F_{a}\left(f_{T a}-f_{T c}\right) S_{2}(t) \\
\frac{I A}{T A} \equiv \frac{f_{I c} Z(t)+F_{a}\left(f_{I a}-f_{I c}\right) S_{2}(t)}{f_{T c} Z(t)+F_{a}\left(f_{T a}-f_{T c}\right) S_{2}(t)}
\end{gathered}
$$

with

$$
\begin{array}{cc}
f_{T c}=\left(1-\frac{10^{-\mathrm{pH}(t)}+K_{c}}{10^{-4.3}+K_{c}}\right) & f_{P c}=\left(1-\frac{10^{-\mathrm{pH}(t)}+K_{c}}{10^{-5.75}+K_{c}}\right) \\
f_{T a}=\left(1-\frac{10^{-\mathrm{pH}(t)}+K_{a}}{10^{-4.3}+K_{a}}\right) & f_{P a}=\left(1-\frac{10^{-\mathrm{pH}(t)}+K_{a}}{10^{-5.75}+K_{a}}\right) \\
F_{a}=\left(\frac{K_{a}}{10^{-\mathrm{pH}(t)}+K_{a}}\right) & f_{I c}=f_{T c}-f_{P c} \\
f_{T a}-f_{P a}
\end{array}
$$

Using Equations (5)-(7), the reference for the true state variables $S_{2}$ and $Z$ that guarantee the digester operational stability can be obtained as follows:

$$
\begin{gathered}
S_{2}^{r}=\frac{T A^{r}\left(f_{I c}-(I A / T A)^{r} f_{T c}\right)}{F_{a}\left(F_{1}+F_{2}\right)} \\
Z^{r}=\frac{T A^{r}-F_{a}\left(f_{T a}-f_{T c}\right) S_{2}^{r}}{f_{T c}}
\end{gathered}
$$

with

$$
\begin{aligned}
& F_{1}=f_{T c}\left((I A / T A)^{r}\left(f_{T a}-f_{T c}\right)-\left(f_{I a}-f_{I c}\right)\right) \\
& F_{2}=\left(f_{T a}-f_{T c}\right)\left(f_{T c}-(I A / T A)^{r} f_{T c}\right)
\end{aligned}
$$

where $S_{2}^{r}$ and $Z^{r}$ are the set-point values for the VFA and strong ions concentrations, respectively, for $T A^{r}$ and $(I A / T A)^{r}$ fulfilling inequalities (3-4). Figures 1 and 2 show the explicit $\mathrm{pH}$ dependence of $S_{2}^{r}$ and $Z^{r}$, respectively. 


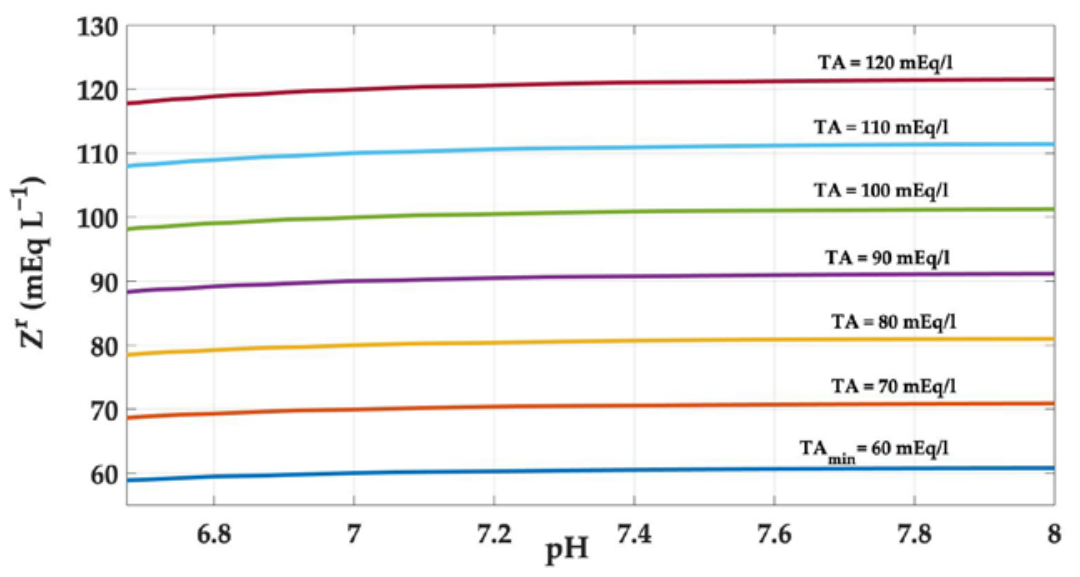

Figure 1. Different values for $Z^{r}$ with $(I A / T A)^{r}=0.3$.

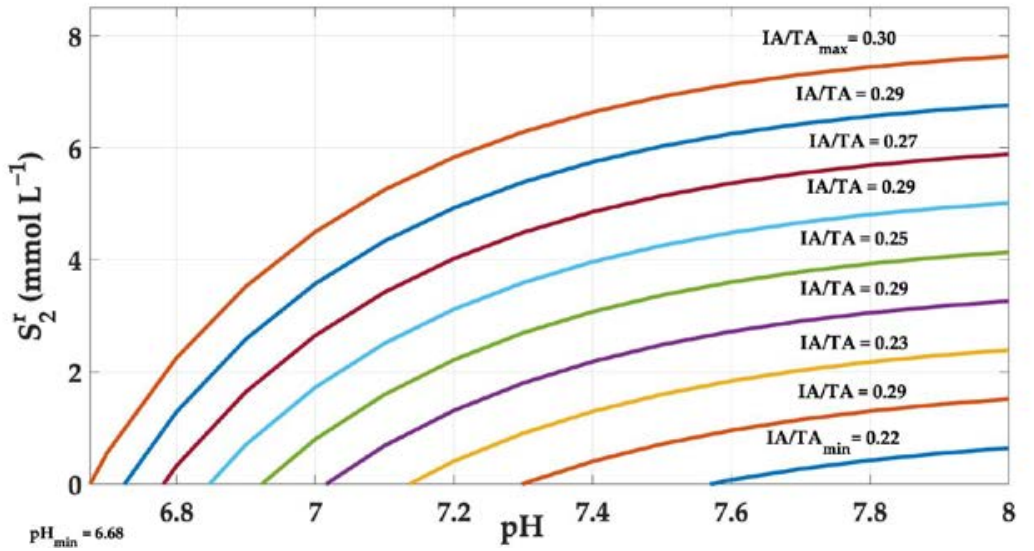

Figure 2. Different values for $S_{2}^{r}$ with $T A^{r}=60 \mathrm{mmol} \mathrm{L}^{-1}$.

Figure 1 also shows that $T A$ is effectively close to $Z$ (for a $\mathrm{pH}$ close to 7 ), while Figure 2 shows how the alkalinity criterion (4) regarding the ratio $I A / T A$ implies a more careful and restrictive choice of $S_{2}^{r}$, mainly for $\mathrm{pH}<7$. Actually, the lower the $\mathrm{pH}$, the reference that should be set for $S_{2}$ is more restrictive. For instance, for $T A^{r}=60 \mathrm{mEq} \mathrm{L}{ }^{-1}$, $(I A / T A)^{r}=0.3$, and the $\mathrm{pH}=6.68, S_{2}^{r}$ is set at zero, as shown in Figure 2, but for a $\mathrm{pH}=6.8$, and at the same $(I A / T A)^{r}=0.3, S_{2}^{r}$ is set at $S_{2}^{r} \approx 2 \mathrm{mmol} \mathrm{L}^{-1}$. Nevertheless, the minimal possible value for criterion (4) is the ratio $I A / T A_{\min }=0.22$, which is attainable only in the interval of $\mathrm{pH} 7.57<\mathrm{pH}<8$, because below these conditions Equation (8) predicts negative $S_{2}^{r}$ values. Thus, an important result in this analysis is the fact that for any pair of values for the alkalinity criteria $T A^{r}$, an $(I A / T A)^{r}$ below $T A_{\min }^{r}=60 \mathrm{mEq} \mathrm{L}{ }^{-1}$, and $(I A / T A)_{\text {min }}^{r}=0.22$, the AD process must operate at a $\mathrm{pH}>8$ to satisfy $S_{2}^{r}>0$. However, such a $\mathrm{pH}$ is off of the operational $\mathrm{pH}$ interval used in $\mathrm{AD}$. In any case, it is clear that while $T A^{r}$ and $(I A / T A)^{r}$ are fixed set-points, $S_{2}^{r}$ and $Z^{r}$ are not, but these are considered as a function of $\mathrm{pH}$.

\subsection{Control Approach}

Once the set-points are established in terms of the true state variables in Model (1), they can be included in the MIMO control laws given by Equations (10)-(12). They have the same mathematical structure as the control laws used in the numerical simulations in [57]. It is worth mentioning that in this work, the control laws were constructed by 
combining exponential Lyapunov functions and a Luenberger observer to estimate the uncertain kinetics. The resulting MIMO control laws are:

$$
\begin{gathered}
D_{1}=\frac{-\hat{\eta}-\lambda_{1} v_{1}}{S_{2}^{i n}-S_{2}} \\
D_{2}=\frac{-D_{1}\left(Z_{1}^{\text {in }}-Z\right)-\lambda_{2} v_{2}}{Z_{2}^{\text {in }}-Z}
\end{gathered}
$$

with

$$
v_{1}=\frac{1-e^{-\frac{1}{2}\left(S_{2}-S_{2}^{r}\right)^{2}}}{\left|S_{2}-S_{2}^{r}\right|}, v_{2}=\frac{1-e^{-\frac{1}{2}\left(Z-Z^{r}\right)^{2}}}{\left|Z-Z^{r}\right|}
$$

and $\lambda_{1}$ and $\lambda_{2}$ being the adaptive parameters that satisfy the inequalities:

$$
0<\lambda_{1}<\max v_{1}, 0<\lambda_{2}<\max v_{2}
$$

Notice that $v_{1}, i=\{1,2\}$, are $v_{1}=f(\mathrm{pH})$. Hence, $\lambda_{i}, i=\{1,2\}$ are actually adaptive parameters that can be suitably chosen by the user, provided that the inequalities (13) are fulfilled. $\eta=k_{2} \mu_{1} X_{1}-k_{3} \mu_{2} X_{2}$ in Model (1) represents the uncertain kinetic terms that can be estimated using the following Luenberger observer:

$$
\begin{aligned}
& \dot{\hat{S}_{2}}=\hat{\eta}+D\left(S_{2}^{i n}-\hat{S}_{2}\right)+\Gamma g_{1}\left(S_{2}-\hat{S}_{2}\right) \\
& \hat{\eta}=\Gamma^{2} g_{2}\left(S_{2}-\hat{S}_{2}\right)
\end{aligned}
$$

where $\mathrm{g}_{1} \mathrm{y} \mathrm{g}_{2}$ are chosen in such a way that the polynomial $s^{2}+\mathrm{g}_{2} s+\mathrm{g}_{1}=0$ is Hurwitz, and $\Gamma$ is the observer gain. In this way the Luenberger observer (14) guarantees that the state vector $\left[S_{2}-\hat{S}_{2}, \eta-\hat{\eta}\right]^{T} \rightarrow \varepsilon$ for $t \rightarrow \varepsilon$, where $\varepsilon$ is a vector of arbitrarily small values around the origin [62]. More details about the general control structure design can be found in [57]. The stability proof for the proposed MIMO control approach (10)-(11), for which $V(t)=e^{\frac{1}{2}\left(y(t)-y^{r}(t)\right)^{2}}-1$, with $y=\left\{S_{2}, Z\right\}$, are Lyapunov functions, also can be found in [57]. Figure 3 is a schematic representation of the proposed MIMO control approach.

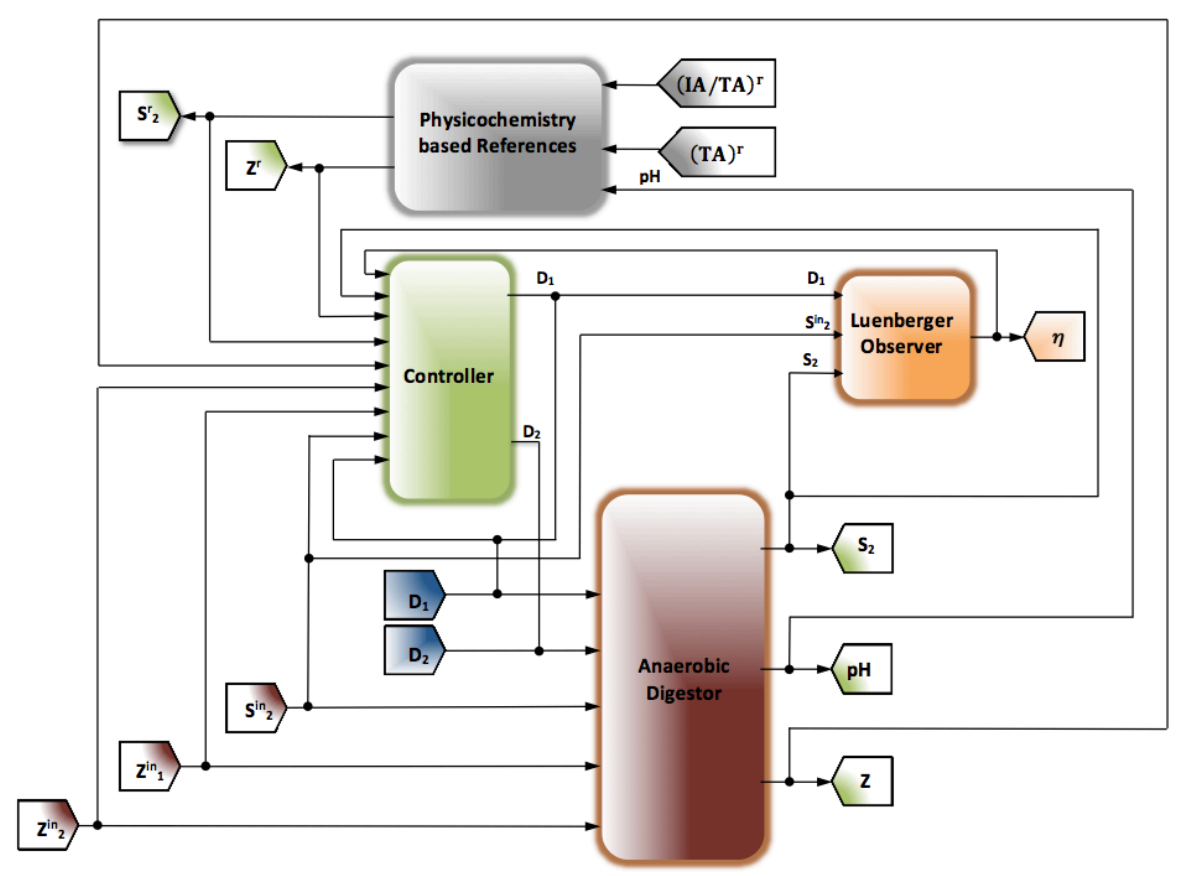

Figure 3. Schematic representation of the proposed MIMO control approach. 


\subsection{Experimental Setup}

Experimental validation was carried out over 12 days on a pilot plant at the French Research Institute for Agriculture, Food and Environment-Laboratory of Environmental Biotechnology (LBE-INRAE) facilities, located in Narbonne, France. The experimental $\mathrm{AD}$ process is an up-flow fixed-bed bioreactor for the treatment of red wine vinasses, with a useful volume of $0.982 \mathrm{~m}^{3}$ [5] (see Figure 4). It is fully instrumented with on-line measurements every half hour of the VFA and bicarbonate (Bic) concentrations, as well as $T A$ and $I A$ using a titrimetric sensor, [63]. Using these measurements, it was also possible to measure $Z$ as $Z=V F A+B i c$. However, it is important to notice that some technical problems required sensor maintenance in the time periods $5.95 \mathrm{~d}<t<6.5 \mathrm{~d}$ and $8.9 \mathrm{~d}<t<9.6 \mathrm{~d}$. As a consequence, measurements on $S_{2}$ and $Z$ as well as $T A$ and $I A$ were not available in these time periods in a proper form (these readings were excessive noise), and as a consequence, they were not used in the calculations and thus excluded in Figures 5-8. Another drawback with the $\mathrm{NaOH}$ dosage pump, in the time period $9.5 \mathrm{~d}<t<10.5 \mathrm{~d}$, prevented $Q_{i n 2}$ to follow its respective control law. During this time period, a default $Q_{i n 2}=0.028 \mathrm{~L} \mathrm{~h}^{-1}$ was used with no important consequences in the MIMO controller performance (as we will discuss later in the paper). The average operating temperature was $35^{\circ} \mathrm{C}$ and it could change $\pm 1{ }^{\circ} \mathrm{C}$ around $35^{\circ} \mathrm{C}$.

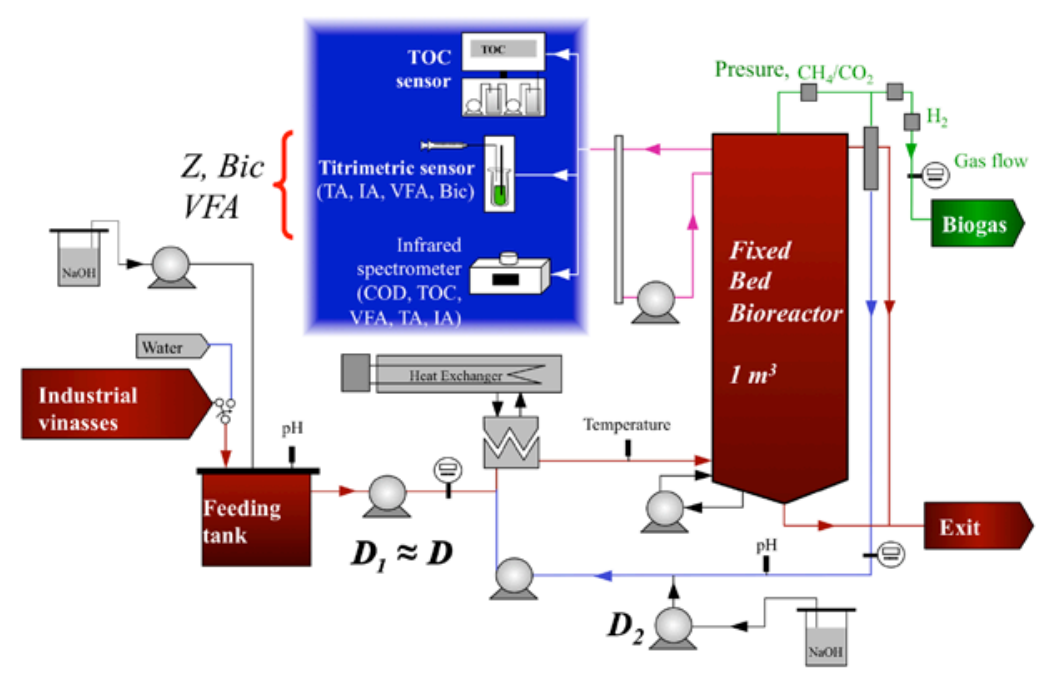

Figure 4. Schematic representation of the anaerobic digestion process and its instrumentation (adapted from [5]).

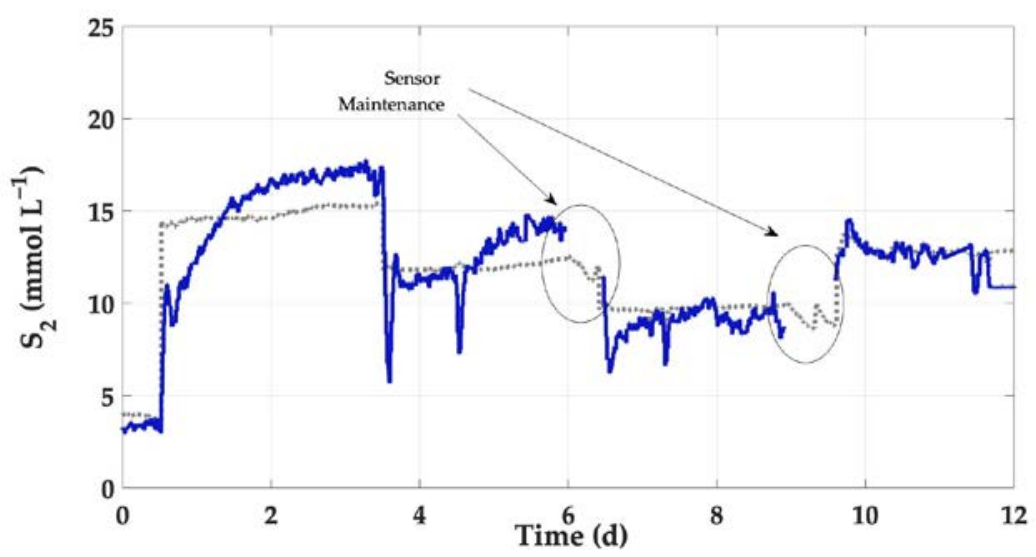

Figure 5. Volatile fatty acids concentration: $(-) S_{2}^{r},(-) S_{2}$ (actual). 


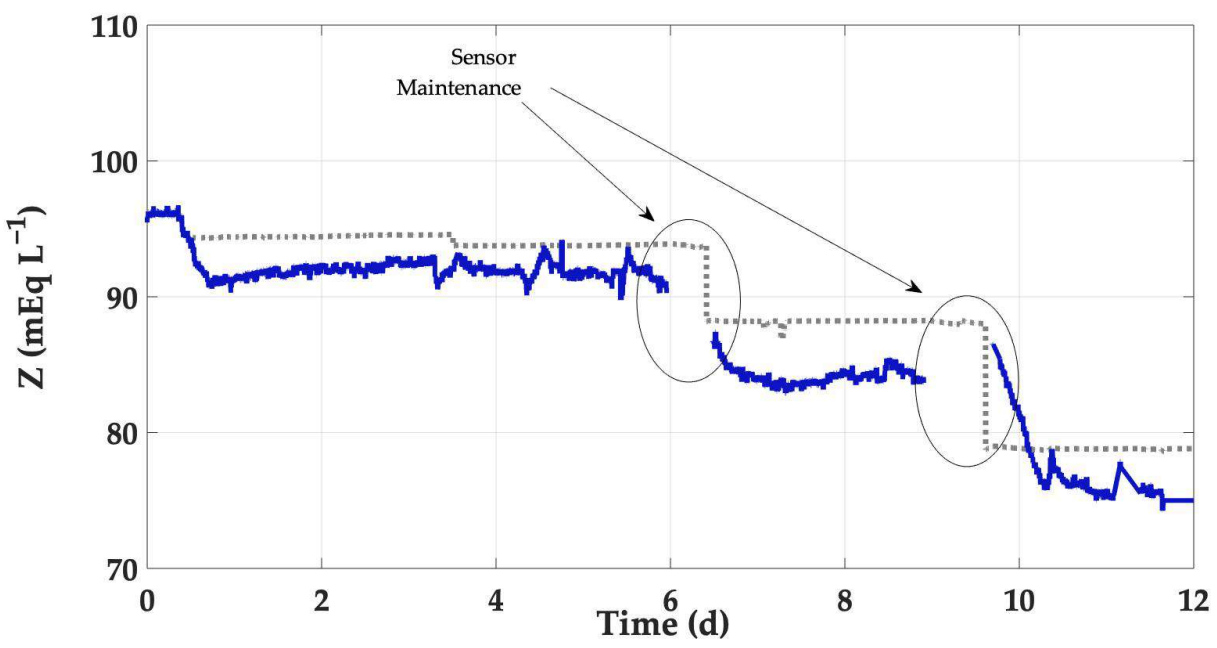

Figure 6. Strong ions concentration: (-) $Z^{r},(-) Z$ (actual).

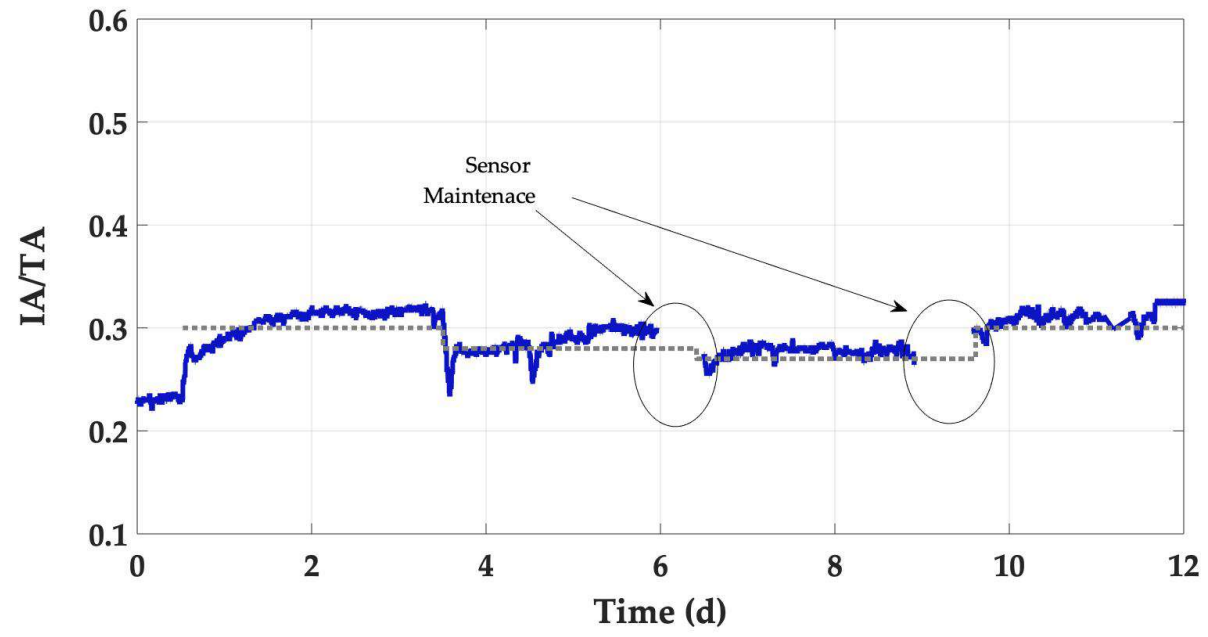

Figure 7. Alkalinities' relationship and its regulation: $(-)(I A / T A)^{r},(-) I A / T A$ (actual).

The COD concentration was measured using a mid-infrared spectrometer (Avatar $380^{\mathrm{TM}}$ FT-IR from Nicolet company modified to remove temperature effects) [64]. With the exception of the titrimetric measurements, which were taken every half hour, the rest of the measurements, such as the recirculation liquid flow rate, reactor temperature, and output biogas composition, were available every $2 \mathrm{~min}$, but not all these measurements are shown in this work. Although measurements on the COD and gas flow rate are not involved in the control approach, they are shown and discussed later together with the overall performance of the system. For a complete description of the anaerobic digester process used in this work as well as its instrumentation, the reader is invited to refer to [5], whose information may be also in complemented by [52]. With respect to titrimetric and COD measurements, the reader may obtain supplementary information in [63] and [64], respectively. The experimental run began operating the AD process in open-loop for $12 \mathrm{~h}$ to adjust the Luenberger observer parameters, which remained without changes for the whole experimental run. According to the alkalinity criteria (3-4), Table 1 shows the values used as alkalinity references through time, while Table 2 shows the parameter used for the Luenberger observer (14). All sensor noisy readings were filtered for better plotting purposes. However, it should be noticed that the whole experiment in the 12 days of duration was carried out entirely online, and calculations for both the Luenberger estimates and control inputs were performed using raw online data. 


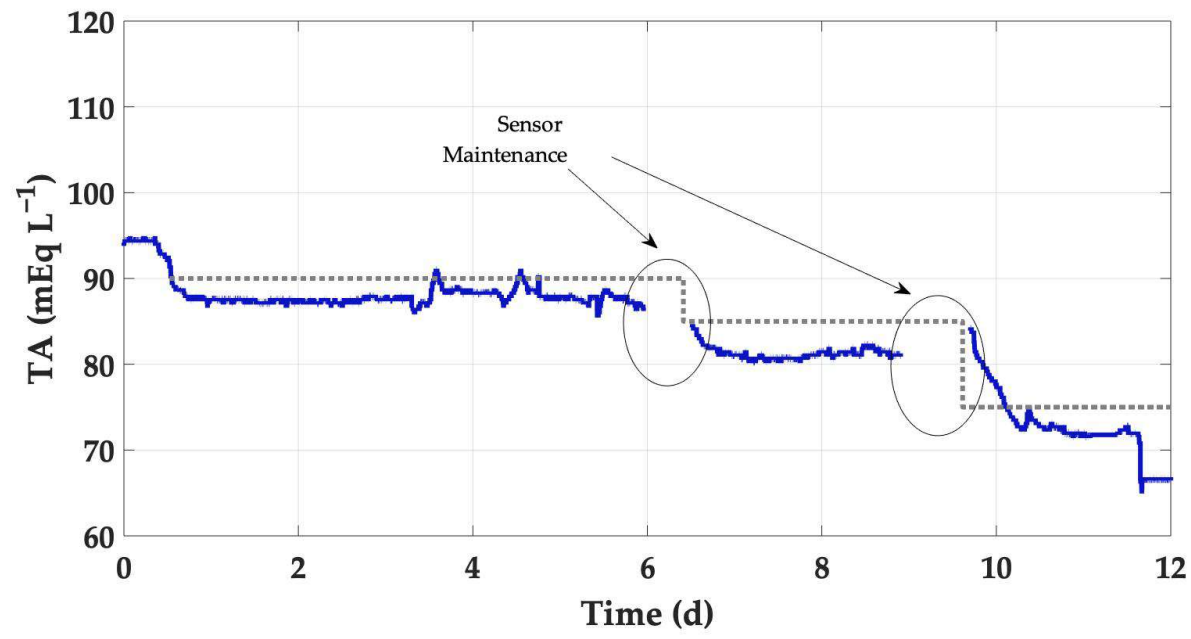

Figure 8. Total alkalinity regulation: (-) $T A^{r},(-) T A$ (actual).

Table 1. Values used as alkalinity references.

\begin{tabular}{ccccc}
\hline Interval Time (d) & $\mathbf{0 . 5}<\boldsymbol{t}<\mathbf{3 . 8}$ & $\mathbf{3 . 8}<\boldsymbol{t}<\mathbf{6}$ & $\mathbf{6}<\boldsymbol{t}<\mathbf{8 . 7}$ & $\mathbf{8 . 7}<\boldsymbol{t}<\mathbf{1 2}$ \\
\hline Period $T(\mathrm{~d})$ & 3.3 & 2.2 & 2.7 & 3.3 \\
$T A^{r}(\mathrm{mEq} \mathrm{L}$ & -1 \\
$(I A / T A)^{r}$ & 90 & 90 & 85 & 75 \\
\hline
\end{tabular}

Table 2. Values used in the Luenberger observer (14).

\begin{tabular}{ccc}
\hline $\boldsymbol{\Gamma}$ & $\mathbf{g}_{1}$ & $\mathbf{g}_{2}$ \\
\hline 0.7 & 2 & 1 \\
\hline
\end{tabular}

Process input concentrations used in the experimental run are shown in Table 3. The measured $S_{2}^{\text {in }}$ was held constant at $S_{2}^{\text {in }}=84.17 \mathrm{mmol} \mathrm{L}^{-1}\left(5050 \mathrm{mg} \mathrm{L}^{-1}\right)$, while $Z_{1}^{\text {in }}$ experienced time variations, and $Z_{2}^{\text {in }}$, the corresponding concentrated $\mathrm{NaOH}$ solution, had a concentration of $18,870 \mathrm{mEq} \mathrm{L}^{-1}$. Notice that since the main control objective was alkalinity and, eventually, the VFA concentration, only the influent composition related to these variables was included in Table 3. Moreover, as the VFA chemical equilibrium constants (and thus pKs) are very close, the AM2 dynamic model only takes into account the more representative of them as the model VFA molecule; i.e., acetic acid, whose chemical and physicochemical properties may represent all of the VFA ones. No other compounds, (i.e., weak acids or bases other than VFA and bicarbonates) affecting alkalinity were found in the red wine vinasses used in this work.

Table 3. Values used as the process input concentrations.

\begin{tabular}{cccc}
\hline Interval Time $\mathbf{( d )}$ & $\mathbf{0 . 5}<\boldsymbol{t}<\mathbf{6}$ & $\mathbf{6}<\boldsymbol{t}<\mathbf{8 . 7}$ & $\mathbf{8 . 7}<\boldsymbol{t}<\mathbf{1 2}$ \\
\hline$S_{2}^{\text {in }}\left(\mathrm{mmol} \mathrm{L}^{-1}\right)$ & 84.17 & 84.17 & 84.17 \\
$Z_{1}^{\text {in }}\left(\mathrm{mEq} \mathrm{L}^{-1}\right)$ & 90 & 80 & 75 \\
$Z_{2}^{\text {in }}\left(\mathrm{mEq} \mathrm{L}^{-1}\right)$ & 18,870 & 18,870 & 18,870 \\
\hline
\end{tabular}

\section{Results and Discussion}

The design of the MIMO controller is based on adaptive robust exponential approaches [57] in order to provide synergy with the microbial growth and activity that have an exponential behavior. Thus, in the same way, the control law also provides synergy 
to $S_{2}$ production-consumption, and biogas production (mainly $\mathrm{CO}_{2}$ ), with the VFA and bicarbonates being the main factors responsible of buffer system capacity, i.e., alkalinities.

As previously described, the control objectives, i.e., the set-points, were first established based on normal operational conditions stated by the alkalinity criteria (3-4), and then formally expressed in the form of state variables based on a physicochemical analysis as in Equations (8) and (9). Since these are functions of $\mathrm{pH}$, which varies with time, then the classical regulation control problem, with constant set-points, shifted into a tracking control problem, with variable set-points instead, which added robustness against $\mathrm{pH}$ variations. Figures 5 and 6 show the behavior of $S_{2}$ and $Z$ around their variable set-point calculated by using Equations (8) and (9) and pH measurements (Figure 9). Clearly, the MIMO control satisfactorily tracked the $S_{2}$ and $Z$ set-point trajectories while satisfying the theoretical alkalinity criteria and preventing VFA accumulation. Thus, even when the alkalinity criteria (3-4) are not involved explicitly or directly in the calculation of the MIMO control law given by Equations (10) and (11), this control law was able to satisfy indirectly the demanded constant reference inequalities of the alkalinities (3-4) in the system.

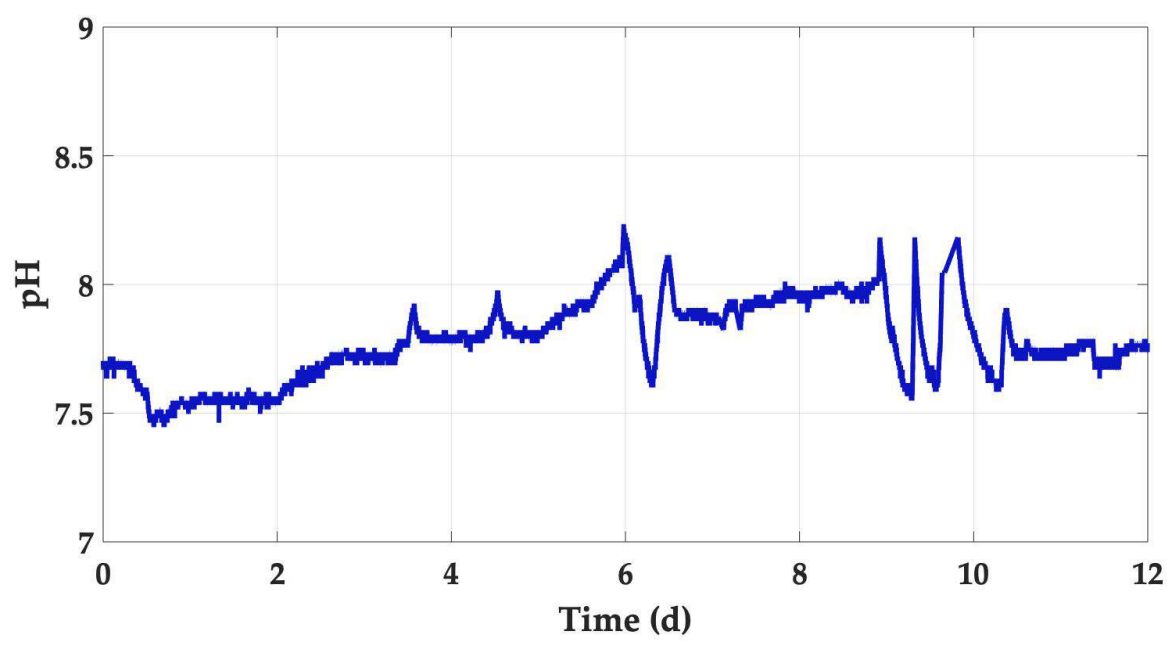

Figure 9. $\mathrm{pH}$ in the digester.

This can be seen in Figures 7 and 8, which complete the picture of the implementation of the MIMO controller on the alkalinity variables, IA/TA and TA, whose responses, although stable, did not meet the predetermined bounds. The behavior of both these variables under closed-loop operation may be improved by changing the bounds on the operational stability criteria. Another possible explanation will be given later in this section.

On the other hand, uncertainties given for the lack of knowledge on microbial growth kinetic is aggravated in $\mathrm{AD}$ systems by the impossibility of measuring biomass concentrations. However, these uncertainties were well addressed with the use of the Luenberger observer (14), which estimated $\eta$ and $S_{2}$. Figure 5 shows only the measurement of $S_{2}$. and its reference given by Equation (8). This estimate is not shown here as a $99 \%$ precision was practically obtained. Besides, what it was actually used in Equation (3) was the direct measurements of $S_{2}$ instead of their estimates.

Figure 10 depicts the estimation of $\eta$, which was held below zero for most of the experimental run except in very brief time periods at $t=0.5 \mathrm{~d}$, when both the Luenberger observer and the control algorithm were applied, and at $t=5.9 \mathrm{~d}$ and $t=8.9 \mathrm{~d}$, when technical problems of the sensors and actuators occurred. It is important to remark that estimates of $\eta<0$ means that the $S_{2}$ consumption rate is faster than its production, and so, substrate inhibition is unlikely to occur. 


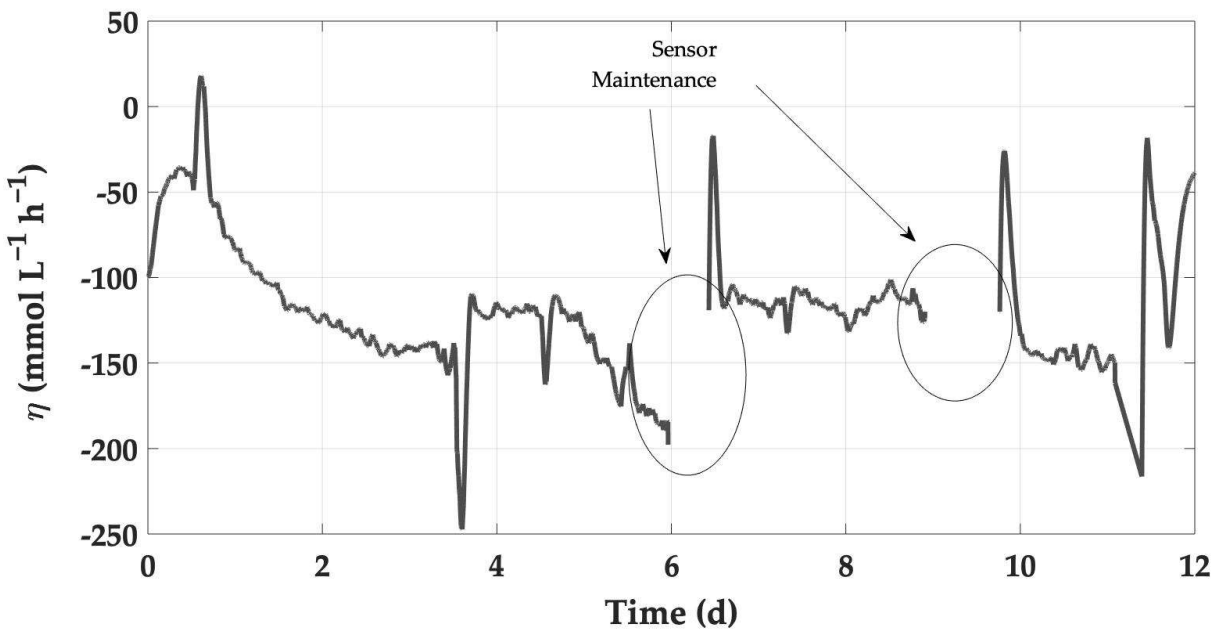

Figure 10. Estimate of $\eta$ given by the Luenberger observer.

Actuator control efforts for both control inputs, i.e., process input flow according to Equation (10) and additional input of concentrated alkali flow given by the supplementary $\mathrm{NaOH}$ supply according to Equation (11), are shown in Figures 11 and 12, respectively. Moreover, it can be seen that the bioreactor was stopped for sensor maintenance several times for less than one day at these short time periods (see Figures 5-8). Even in this extrauncertain scenario, once the system was reestablished, the Luenberger observer as well as the proposed MIMO robust adaptive control approach recovered almost immediately their high performance, as seen in Figures 10-12, demonstrating its robustness against sensors faults.

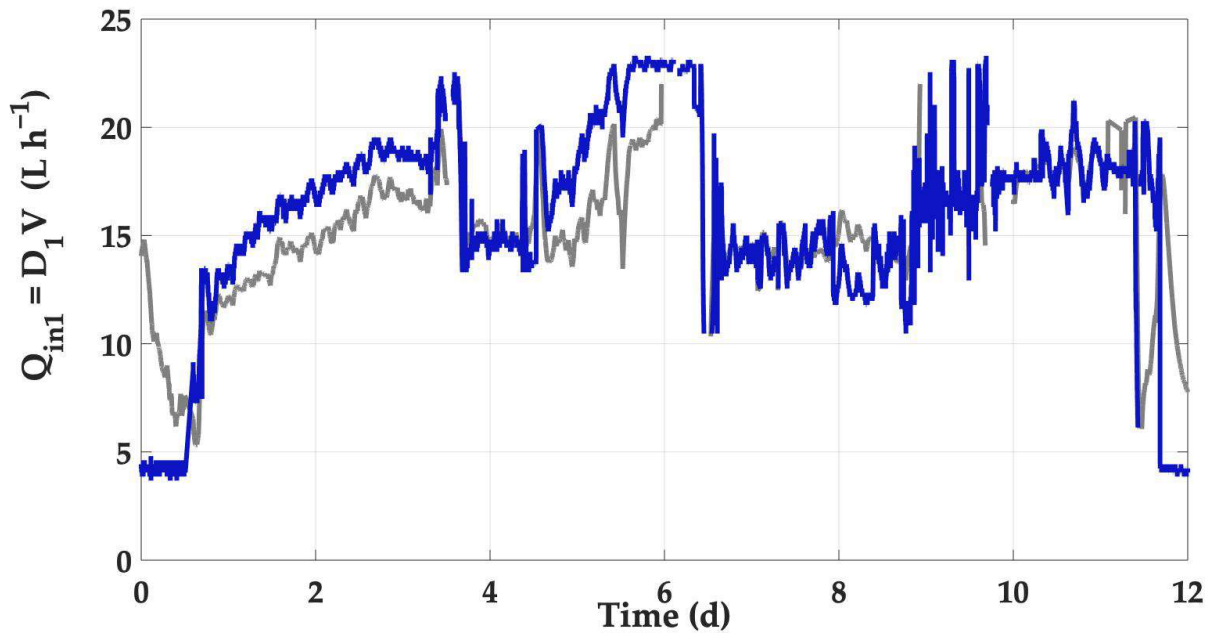

Figure 11. Input flow rate: (-) $\hat{D}_{1}$ (calculated), (-) $D_{1}$ (actual). 


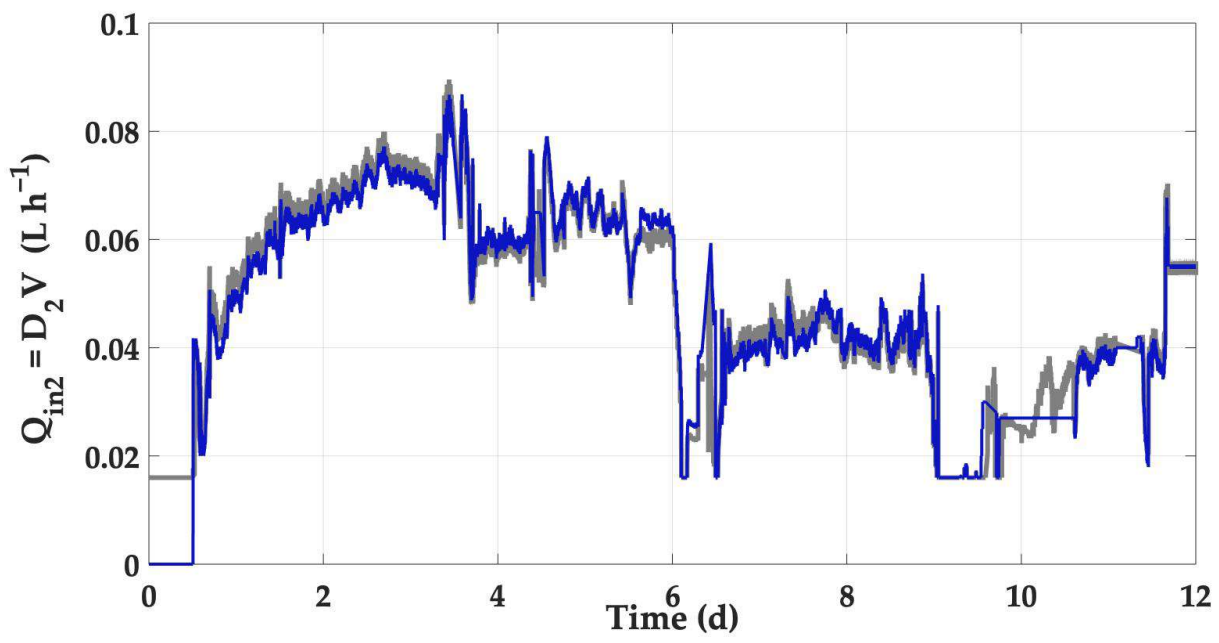

Figure 12. Alkali input flow rate: (-) $\hat{D}_{2}$ (calculated), (-) $D_{2}$ (actual).

However, there were differences between the values calculated by the MIMO control law and the actual flows given by the respective pumps. These differences appear to be more significant in the case of process input flow and less significant in the case of $\mathrm{NaOH}$ supply. Nevertheless, since the alkali solution was concentrated, the difference in this flow rate also has special relevance. Such differences may explain why $T A^{r}$ and $(I A / T A)^{r}$ were not strictly satisfied. Indeed, with such a high actuator sensitivity, it was not possible to achieve the flows demanded with the due accuracy. This fact inferred and led the system under conditions slightly different from what was expected, as shown in Figures 5-8. Another possible factor, which in fact is in turn derived from the former, is that because of these technical difficulties, and because it was an online experimental validation (with all that this entails), the regulation on $Z$ and $S_{2}$ could be achieved only in a neighborhood around their respective set-points. This regulation was relatively very close to the desired one, especially in $S_{2}$. If it is taken into account that $I A$ is mainly due to VFA by $80 \%($ at $\mathrm{pH}=7)$ [20], this would help to explain how the regulation on $I A / T A$ was relatively more performing than on $T A$. Furthermore, $T A^{r}$ was established above $60 \mathrm{mEq} \mathrm{L}^{-1}$, and $T A$ was effectively held in the whole experiment above this value. This feature together with the relatively good $I A / T A$ regulation may explain the overall good performance of the system during this experimental run. Besides, in Figures 13 and 14, the system behavior of the other variables, such as COD and gaseous flow rate $Q_{g a s}$, can be seen. Even though these variables were not expressly regulated, they remained in values both appropriate and suitable as COD $<3 \mathrm{~g} \mathrm{~L}^{-1}$, and $Q_{\text {gas }}$ around $50 \mathrm{~L} \mathrm{~h}^{-1}$ on average.

Furthermore, notice that the bioreactor reaches four stable regions induced by the four references stated in Table 1. It is pointed out that the proposed MIMO controller was implemented to drive the operating conditions to satisfy certain bounds on $T A$ and the ratio $I A / T A$, and the involved state variables $S_{2}$ and $Z$. The behavior of other variables, such as COD and $Q_{g a s}$, remained within reasonable operation bounds. The actual manipulated variables $Q_{i n 1}$ and $Q_{i n 2}$ (proportional to $D_{1}$ and $D_{2}$, respectively) showed no saturation during the whole experimental run. 


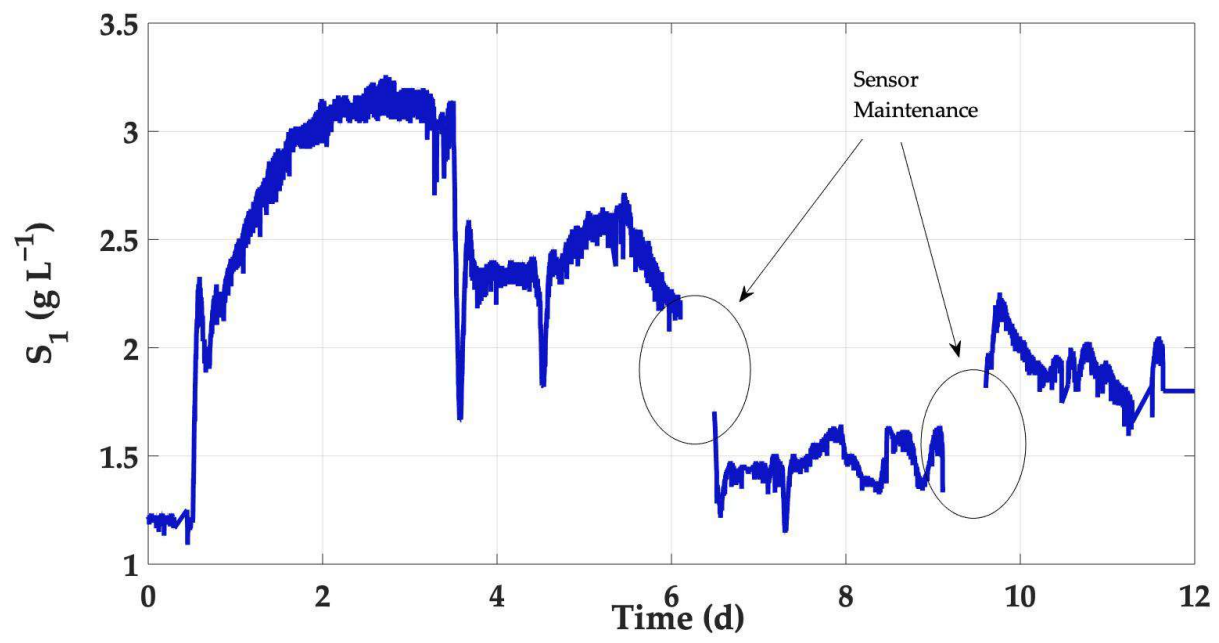

Figure 13. Chemical oxygen demand in the digester.

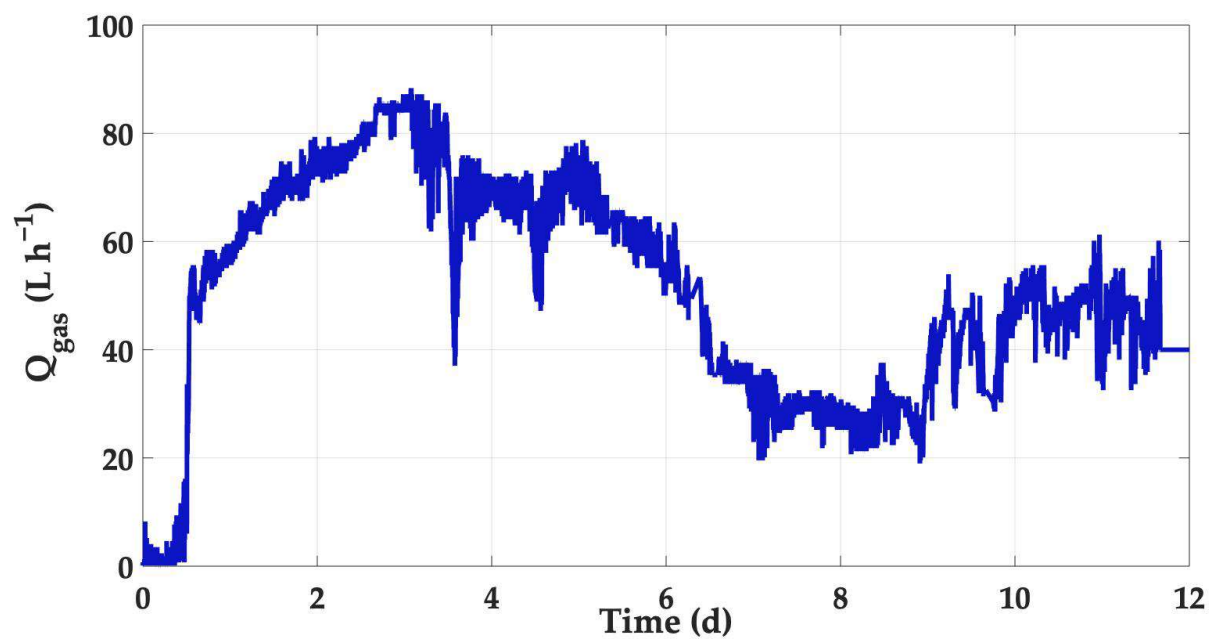

Figure 14. Produced gaseous flow rate.

Another aspect that can be discussed, is the hydraulic retention time (HRT) observed along the experiment and its relationship with OS issues. Notice that, with a $15 \mathrm{~L} \mathrm{~h}^{-1}$ average flow rate (see Figure 11) and a volume $\mathrm{V}=0.982 \mathrm{~m}^{3}$, the average HRT $=2.72 \mathrm{~d}$. Moreover, notice that, in this work, we have carried out four set-point changes (see Table 1), and each one had a time duration $T \leq \mathrm{HRT}$, except in the time interval $3.8<t<6$, but in all cases just in time for achieving a steady state on the controlled variables, and to switch to the following one. In this way, the proposed MIMO control approach proved robustness and usefulness in real experimental implementation on an anaerobic digestion process used for the treatment of agro-industrial wastewater.

Finally, it should be noticed that a wholly operationally stable, steady-state operation could be widely desirable. Such an objective is possible, provided that the MIMO control objectives are extended properly. On one hand, reference values (8) and (9), i.e., $S_{2}^{r}$ and $Z^{r}$, are functions of the constant alkalinity references, but in turn, they are also functions of $\mathrm{pH}$, which can vary in time as a function of environmental factors, such as temperature, and other ones. As a consequence, $S_{2}^{r}$ and $Z^{r}$ are varying. Notice, however, that the true control objectives are $T A$ and the ratio $I A / T A$. In this sense, by fulfilling these control objectives, OS is achieved, which was the global objective of the present work. Nevertheless, if a more ambitious objective is intended, i.e., to keep the system under OS, and at the same time to regulate other variables such as COD, gas production, or the same VFA concentration, the MIMO strategy should be adapted as a consequence. For instance, using 
the same bioreactor and similar control approaches, VFA regulation only [33] or COD regulation only [50] already have been studied. In addition, in this work, the simultaneous regulation of alkalinities and VFA was addressed. Thus, the simultaneous regulation of alkalinities, VFA, and COD should be the next step in order to achieve both effective organic decontamination and efficient OS conditions.

\section{Conclusions and Future Work}

A multivariable control approach was proposed to regulate the alkalinities in anaerobic digestion processes and successfully implemented on an anaerobic $0.982 \mathrm{~m}^{3}$ up-flow fixedbed bioreactor for the treatment of agro-industrial wastewater located in Narbonne, France, over 12 days in which several alkalinity set-points were tested. It was shown that such a control scheme satisfactorily tracks the set-point trajectories of the alkalinities in the face of time-varying $\mathrm{pH}$, parameter uncertainties, and unknown microbial kinetics, while preventing the AD process to breakdown due to excessive accumulation of VFAs. The results also showed that this control scheme may be easily scaled-up and applied in actual wastewater treatment plants. Simultaneous automatic control of alkalinities, VFA, and COD in a wholly MIMO control approach is currently investigated as future work.

Author Contributions: Conceptualization, V.A.-G. (Víctor Alcaraz-González), F.A.F.-S. and J.-P.S.; methodology, V.A.-G. (Víctor Alcaraz-González), V.G.-A. (Víctor González-Alvarez) and J.-P.S.; software, F.A.F.-S.; validation, V.A.-G. (Víctor Alcaraz-González), F.A.F.-S. and J.-P.S.; formal analysis, V.A.-G. (Víctor Alcaraz-González) and F.A.F.-S.; investigation, V.A.-G. (Víctor Alcaraz-González) and F.A.F.-S.; data curation, V.A.-G. (Víctor Alcaraz-González) and J.-P.S.; writing-original draft, V.A.-G. (Víctor Alcaraz-González); writing-review \& editing, V.A.-G. (Víctor Alcaraz-González), F.A.F.-S., V.G.-A. (Víctor González-Alvarez) and J.-P.S.; visualization, V.G.-A. (Víctor González-Alvarez) and J.-P.S.; supervision, V.A.-G. (Víctor Alcaraz-González) and V.G.-A. (Víctor González-Alvarez); project administration, J.-P.S. and V.G.-A. (Víctor González-Alvarez). All authors have read and agreed to the published version of the manuscript.

Funding: This research received no external funding.

Institutional Review Board Statement: Not applicable.

Informed Consent Statement: Not applicable.

Data Availability Statement: The data presented in this study are available on request from the corresponding author.

Conflicts of Interest: The authors declare no conflict of interest.

\section{References}

1. Mata-Alvarez, J.; Macé, S.; Llabrés, P. Anaerobic digestion of organic solid wastes. An overview of research achievements and perspectives. Bioresour. Technol. 2000, 74, 3-16. [CrossRef]

2. Metcalf, E.; Eddy, H.P. Wastewater Engineering: Treatment, Disposal, and Reuse, 4th ed.; McGraw-Hill: New York, NY, USA, 2004; 1819 p.

3. Mata-Alvarez, J.; Dosta, J.; Romero-Güiza, M.; Fonoll, X.; Peces, M.; Astals, S. A critical review on anaerobic co-digestion achievements between 2010 and 2013. Renew. Sustain. Energy Rev. 2014, 36, 412-427. [CrossRef]

4. Rehman, M.L.U.; Iqbal, A.; Chang, C.; Li, W.; Ju, M. Anaerobic digestion. Water Environ. Res. 2019, 91, 1253-1271. [CrossRef]

5. Steyer, J.-P.; Bouvier, J.; Conte, T.; Gras, P.; Sousbie, P. Evaluation of a four year experience with a fully instrumented anaerobic digestion process. Water Sci. Technol. 2002, 45, 495-502. [CrossRef] [PubMed]

6. Zhang, R.; El-Mashad, H.M.; Hartman, K.; Wang, F.; Liu, G.; Choate, C.; Gamble, P. Characterization of food waste as feedstock for anaerobic digestion. Bioresour. Technol. 2007, 98, 929-935. [CrossRef] [PubMed]

7. Appels, L.; Baeyens, J.; Degrève, J.; Dewil, R. Principles and potential of the anaerobic digestion of waste-activated sludge. Prog. Energy Combust. Sci. 2008, 34, 755-781. [CrossRef]

8. Chan, Y.J.; Chong, M.F.; Law, C.L.; Hassell, D. A review on anaerobic-aerobic treatment of industrial and municipal wastewater. Chem. Eng. J. 2009, 155, 1-18. [CrossRef]

9. Angelidaki, I.; Ellegaard, L.; Ahring, B.K. Applications of the Anaerobic Digestion Process. Blue Biotechnol. 2003, 82, 1-33. [CrossRef]

10. Mir, M.A.; Hussain, A.; Verma, C. Design considerations and operational performance of anaerobic digester: A review. Cogent Eng. 2016, 3. [CrossRef] 
11. Holm-Nielsen, J.; Al Seadi, T.; Oleskowicz-Popiel, P. The future of anaerobic digestion and biogas utilization. Bioresour. Technol. 2009, 100, 5478-5484. [CrossRef]

12. Donoso-Bravo, A.; Mailier, J.; Martin, C.; Rodríguez, J.; Aceves-Lara, C.A.; Wouwer, A.V. Model selection, identification and validation in anaerobic digestion: A review. Water Res. 2011, 45, 5347-5364. [CrossRef] [PubMed]

13. Bernard, O.; Chachuat, B.; Hélias, A.; Rodriguez, J. Can we assess the model complexity for a bioprocess: Theory and example of the anaerobic digestion process. Water Sci. Technol. 2006, 53, 85-92. [CrossRef] [PubMed]

14. Godon, J.-J.; Zumstein, E.; Dabert, P.; Habouzit, F.; Moletta, R. Microbial $16 \mathrm{~S}$ rDNA diversity in an anaerobic digester. Water Sci. Technol. 1997, 36, 49-55. [CrossRef]

15. Delbã “s, C.; Moletta, R.; Godon, J.-J.; Delbès, C.; Moletta, R. Bacterial and archaeal 16S rDNA and 16S rRNA dynamics during an acetate crisis in an anaerobic digestor ecosystem. FEMS Microbiol. Ecol. 2001, 35, 19-26. [CrossRef]

16. Husain, A. Mathematical models of the kinetics of anaerobic digestion-A selected review. Biomass Bioenergy 1998, 14, 561-571. [CrossRef]

17. Gavala, H.N.; Angelidaki, I.; Ahring, B.K. Kinetics and Modeling of Anaerobic Digestion Process. Blue Biotechnol. 2003, 81, 57-93. [CrossRef]

18. Angelidaki, I.; Boe, K.; Ellegaard, L. Effect of operating conditions and reactor configuration on efficiency of full-scale biogas plants. Water Sci. Technol. 2005, 52, 189-194. [CrossRef]

19. Méndez-Acosta, H.; Palacios-Ruiz, B.; Alcaraz-González, V.; González-Álvarez, V.; Garcia-Sandoval, J.P. A robust control scheme to improve the stability of anaerobic digestion processes. J. Process. Control 2010, 20, 375-383. [CrossRef]

20. Ripley, A.L.E.; Boyle, W.C.; Converse, J.C. Improved alkalimetric for anaerobic digestion wastes monitoring of municipal sludge. Water Pollut. Contron. Fed. 1986, 58, 406-411.

21. Moosbrugger, R.E.; Wentzel, M.C.; Ekama, G.A.; Marais, G.v.R. Weak acid/bases and pH control in anaerobic systems-A review. Watar SA 1993, 19, 1-10.

22. Chen, Y.; Cheng, J.J.; Creamer, K.S. Inhibition of anaerobic digestion process: A review. Bioresour. Technol. 2008, 99, 4044-4064. [CrossRef] [PubMed]

23. Chen, S.; Zhang, J.; Wang, X. Effects of alkalinity sources on the stability of anaerobic digestion from food waste. Waste Manag. Res. 2015, 33, 1033-1040. [CrossRef] [PubMed]

24. Jarrell, K.F.; Saulnier, M.; Ley, A. Inhibition of methanogenesis in pure cultures by ammonia, fatty acids, and heavy metals, and protection against heavy metal toxicity by sewage sludge. Can. J. Microbiol. 1987, 33, 551-554. [CrossRef]

25. Fagbohungbe, M.; Herbert, B.M.; Hurst, L.; Ibeto, C.N.; Li, H.; Usmani, S.Q.; Semple, K. The challenges of anaerobic digestion and the role of biochar in optimizing anaerobic digestion. Waste Manag. 2017, 61, 236-249. [CrossRef] [PubMed]

26. Buyukkamaci, N.; Filibeli, A. Volatile fatty acid formation in an anaerobic hybrid reactor. Process. Biochem. 2004, 39, 1491-1494. [CrossRef]

27. Hess, J.; Bernard, O. Design and study of a risk management criterion for an unstable anaerobic wastewater treatment process. J. Process. Control 2008, 18, 71-79. [CrossRef]

28. Liu, B.Y.; Pfeffer, J.T.; Suidan, M.T. Equilibrium Model of Anaerobic Reactors. J. Environ. Eng. 1995, 121, 58-65. [CrossRef]

29. Florencio, L.; Field, J.A.; Van Langerak, A.; Lettinga, G. pH-Stability in anaerobic bioreactors treating methanolic wastewaters. Water Sci. Technol. 1966, 33, 177-184. [CrossRef]

30. Lahav, O.; Morgan, B. Titration methodologies for monitoring of anaerobic digestion in developing countries?a review. J. Chem. Technol. Biotechnol. 2004, 79, 1331-1341. [CrossRef]

31. Wang, X.; Bai, X.; Li, Z.; Zhou, X.; Cheng, S.; Sun, J.; Liu, T. Evaluation of artificial neural network models for online monitoring of alkalinity in anaerobic co-digestion system. Biochem. Eng. J. 2018, 140, 85-92. [CrossRef]

32. Barampouti, E.M.P.; Mai, S.T.; Vlyssides, A.G. Dynamic Modeling of the Ratio Volatile Fatty Acids/Bicarbonate Alkalinity in a UASB Reactor for Potato Processing Wastewater Treatment. Environ. Monit. Assess. 2005, 110, 121-128. [CrossRef] [PubMed]

33. Méndez-Acosta, H.O.; Palacios-Ruiz, B.; Alcaraz-González, V.; Steyer, J.-P.; González-Álvarez, V.; Latrille, E. Robust Control of Volatile Fatty Acids in Anaerobic Digestion Processes. Ind. Eng. Chem. Res. 2008, 47, 7715-7720. [CrossRef]

34. Garcia-Sandoval, J.P.; Méndez-Acosta, H.; González-Alvarez, V.; Schaum, A.; Alvarez, J. VFA robust control of an anaerobic digestion pilot plant: Experimental implementation. IFAC-PapersOnLine 2016, 49, 973-977. [CrossRef]

35. Batstone, D.J.; Keller, J.; Angelidaki, I.; Kalyuzhnyi, S.V.; Pavlostathis, S.G.; Rozzi, A.; Sanders, W.T.M.; Siegrist, H.; Vavilin, V.A. The IWA Anaerobic Digestion Model No 1 (ADM1). Water Sci. Technol. 2002, 45, 65-73. [CrossRef] [PubMed]

36. Montiel-Escobar, J.L.; Alcaraz-González, V.; Méndez-Acosta, H.O.; González-Álvarez, V. ADM1-Based Robust Interval Observer for Anaerobic Digestion Processes. CLEAN Soil Air Water 2012, 40, 933-940. [CrossRef]

37. Torres Zúñiga, I.; Villa-Leyva, A.; Vargas, A.; Buitrón, G. Experimental validation of online monitoring and optimization strategies applied to a biohydrogen production dark fermenter. Chem. Eng. Sci. 2018, 190, 48-59. [CrossRef]

38. Giovannini, G.; Sbarciog, M.; Steyer, J.-P.; Chamy, R.; Wouwer, A.V. On the derivation of a simple dynamic model of anaerobic digestion including the evolution of hydrogen. Water Res. 2018, 134, 209-225. [CrossRef]

39. Patón, M.; González-Cabaleiro, R.; Rodríguez, J. Activity corrections are required for accurate anaerobic digestion modelling. Water Sci. Technol. 2018, 77, 2057-2067. [CrossRef]

40. Zhang, Y.; Piccard, S.; Zhou, W. Improved ADM1 model for anaerobic digestion process considering physico-chemical reactions. Bioresour. Technol. 2015, 196, 279-289. [CrossRef] 
41. Shi, E.; Li, J.; Leu, S.-Y.; Antwi, P. Modeling the dynamic volatile fatty acids profiles with $\mathrm{pH}$ and hydraulic retention time in an anaerobic baffled reactor during the startup period. Bioresour. Technol. 2016, 222, 49-58. [CrossRef]

42. Xue, L.; Li, D.; Xi, Y. Nonlinear model predictive control of anaerobic digestion process based on reduced ADM1. In Proceedings of the 2015 10th Asian Control Conference (ASCC), Kota Kinabalu, Malaysia, 31 May-3 June 2015; IEEE: New York, NY, USA, 2015; pp. 1-6.

43. Hassam, S.; Ficara, E.; Leva, A.; Harmand, J. A generic and systematic procedure to derive a simplified model from the anaerobic digestion model No. 1 (ADM1). Biochem. Eng. J. 2015, 99, 193-203. [CrossRef]

44. Kiely, G.; Tayfur, G.; Dolan, C.; Tanji, K. Physical and mathematical modelling of anaerobic digestion of organic wastes. Water Res. 1997, 31, 534-540. [CrossRef]

45. Bernard, O.; Hadj-Sadok, Z.; Dochain, D.; Genovesi, A.; Steyer, J.-P. Dynamical model development and parameter identification for an anaerobic wastewater treatment process. Biotechnol. Bioeng. 2001, 75, 424-438. [CrossRef] [PubMed]

46. Theilliol, D.; Ponsart, J.-C.; Harmand, J.; Join, C.; Gras, P. On-line estimation of unmeasured inputs for anaerobic wastewater treatment processes. Control Eng. Pr. 2003, 11, 1007-1019. [CrossRef]

47. Didi, I.; Dib, H.; Cherki, B. A Luenberger-type observer for the AM2 model. J. Process. Control 2015, 32, 117-126. [CrossRef]

48. Rodriguez-Liñan, A.; Quiroz, G.; Femat, R.; Méndez-Acosta, H.; de León, J. An adaptive observer for operation monitoring of anaerobic digestion wastewater treatment. Chem. Eng. J. 2015, 269, 186-193. [CrossRef]

49. Vargas, A.; Sepíuveda-Gálvez, A.; Barrios-Pérez, J.D. A fast extremum-seeking approach for the methanisation of organic waste in an anaerobic bioreactor. IFAC-PapersOnLine 2019, 52, 269-274. [CrossRef]

50. Alcaraz-González, V.; Harmand, J.; Rapaport, A.; Steyer, J.-P.; González-Álvarez, V.; Pelayo-Ortiz, C. Robust interval-based regulation for anaerobic digestion processes. Water Sci. Technol. 2005, 52, 449-456. [CrossRef]

51. Bernard, O.; Chachuat, B.; Hélias, A.; Le Dantec, B.; Sialve, B.; Steyer, J.-P.; Lardon, L.; Neveu, P.; Lambert, S.; Gallop, J.; et al. An integrated system to remote monitor and control anaerobic wastewater treatment plants through the internet. Water Sci. Technol. 2005, 52, 457-464. [CrossRef]

52. Steyer, J.-P.; Bernard, O.; Batstone, D.; Angelidaki, I. Lessons learnt from 15 years of ICA in anaerobic digesters. Water Sci. Technol. 2006, 53, 25-33. [CrossRef]

53. Jimenez, J.; Latrille, E.; Harmand, J.; Robles, Á.; Ferrer, J.; Gaida, D.; Wolf, C.; Mairet, F.; Bernard, O.; Alcaraz-Gonzalez, V.; et al. Instrumentation and control of anaerobic digestion processes: A review and some research challenges. Rev. Environ. Sci. Bio/Technol. 2015, 14, 615-648. [CrossRef]

54. Attar, S.; Haugen, F. Model-based optimal recovery of methane production in an anaerobic digestion reactor. Model. Identif. Control A Nor. Res. Bull. 2020, 41, 121-128. [CrossRef]

55. Hmissi, M.; Harmand, J.; Alcaraz-Gonzalez, V.; Shayeb, H. Evaluation of alkalinity spatial distribution in an up-flow fixed bed anaerobic digester. Water Sci. Technol. 2017, 77, 948-959. [CrossRef] [PubMed]

56. Kil, H.; Li, D.; Xi, Y.; Li, J. Model predictive control with on-line model identification for anaerobic digestion processes. Biochem. Eng. J. 2017, 128, 63-75. [CrossRef]

57. Alcaraz-González, V.; Fregoso-Sanchez, F.A.; Mendez-Acosta, H.O.; Gonzalez-Alvarez, V. Robust Regulation of Alkalinity in Highly Uncertain Continuous Anaerobic Digestion Processes. CLEAN Soil Air Water 2013, 41, 1157-1164. [CrossRef]

58. Alcaraz-Gonzalez, V.; Harmand, J.; Alain, R.; Steyer, J.P.; Gonzalez-Alvarez, V.; Pelayo-Ortiz, C. Software sensors for uncertain wastewater treatment processes: A new approach based on interval observers. Water Res. 2002, 36, 2515-2524. [CrossRef]

59. Bastin, G.; Dochain, D. On-Line Estimation and Adaptive Control of Bioreactors; Elsevier: Amsterdam, The Netherlands, 1990; 379p.

60. Alcaraz-Gonzalez, V. Estimation et Commande Robustes non Linéaires des Procédés Biologiques de Dépollution des Eaux usées: Application a la Digestion Anaérobie. Ph.D. Thesis, Université de Perpignan, Perpignan, France, 2001.

61. Drosg, B. Process Monitoring in Biogas Plants; IEA Bioenergy: Paris, France, 2013.

62. Palacios-Ruiz, B.; Méndez-Acosta, H.; Alcaraz-González, V.; González-Álvarez, V.; Pelayo-Ortiz, C. Regulation of Volatile Fatty Acids and Total Alkalinity in Anaerobic Digesters. IFAC Proc. Vol. 2008, 41, 13611-13616. [CrossRef]

63. Bouvier, J.C.; Steyer, J.P.; Conte, T.; Gras, P.; Delgenes, J.P. On-line titrimetric sensor for the control of anaerobic digestión processes. In Proceedings of the VII Latin American Workshop and Symposium on Anaerobic Digestion, Merida, Mexico, 22-25 October 2002; IWA: London, UK; pp. 65-68.

64. Steyer, J.-P.; Bouvier, J.; Conte, T.; Gras, P.; Harmand, J.; Delgenes, J. On-line measurements of COD, TOC, VFA, total and partial alkalinity in anaerobic digestion processes using infra-red spectrometry. Water Sci. Technol. 2002, 45, 133-138. [CrossRef] 